\title{
Biocontrol of Fusarium oxysporum f. sp. vasinfectum With Bacillus spp. Strains
}

\author{
Sandro C. L. Montalvão ${ }^{1}$, Marcelo T. de Castro $^{2}$, Luiz E. B. Blum ${ }^{3} \&$ Rose Gomes Monnerat $^{4}$ \\ ${ }^{1}$ Moara Bioestimulantes Agroambientais, Brasília, DF, Brazil \\ ${ }^{2}$ Departamento de Agronomia, Centro Universitário ICESP, Brasília, DF, Brazil \\ ${ }^{3}$ Departamento de Fitopatologia, Instituto de Ciências Biológicas, Universidade de Brasília, Brasília, DF, Brazil \\ ${ }^{4}$ Prédio de Controle Biológico, Embrapa Recursos Genéticos e Biotecnologia, Brasília, DF, Brazil \\ Correspondence: Sandro C. L. Montalvão, Moara Bioestimulantes Agroambientais, Setor Econômico de \\ Sobradinho, Quadra 11, Lote 16, Brasília, CEP 73020-411, DF, Brazil. Tel: 55-61-98118-7202. E-mail: \\ sandro.coelho@yahoo.com.br
}

Received: March 20, 2020

Accepted: July 7, $2021 \quad$ Online Published: August 15, 2021

doi:10.5539/jas.v13n9p1

URL: https://doi.org/10.5539/jas.v13n9p1

The research is financed by National Council for Scientific and Technological Development (CNPq).

\begin{abstract}
The wilt caused by Fusarium oxysporum f.sp. vasinfectum in cotton is one of the main diseases of this crop. The pathogen is difficult to control because it produces chlamydospores, which allows it to survive in the soil for long periods without the presence of its main host. The control of this disease is based on varieties with some resistance, certified seeds, and fungicides used to treat seeds. Thus, the development of control alternatives is needed to increase the number of resources to manage this disease in the field. Bacillus are bioregulators and antagonists of several important phytopathogens. Therefore, the objective of this work was to select strains of Bacillus (Paenibacillus alvei, Bacillus thuringiensis, B. megaterium, and B. lentus), whose metabolites are toxic to $F$. oxysporum in laboratory and greenhouse conditions, in addition to adjusting in vitro methodologies to perform and evaluate selection tests. This work determined the best culture medium for the direct confrontation assays, proposed a grading scale to facilitate decisions about selection with the dual tests, identified among the strains selected in the confrontation assays those that produce volatile and non-volatile metabolites toxic to $F$. oxysporum, and tested these selected strains for disease control during seed germination in greenhouse trials. In last test, some strains of Bacillus had a potential protective effect during the germination of cotton seeds.
\end{abstract}

Keywords: antagonism, biological control, non-volatile metabolites, volatile metabolites, PGPRs, seed treatment

\section{Introduction}

Brazil is the fifth largest cotton (Gossypium hirsutum L.) producer with production areas in 15 states, but $85 \%$ of the planted area is concentrated in the states of Mato Grosso and Bahia (CONAB, 2021). This crucial national agricultural sector has undergone important transformations in the last 20 years and is today one of the most modern in agriculture (Borém \& Freire, 2014). The sector moves large financial capital, employing many people and generating foreign currency for the country. Therefore, cotton is considered one of the branches of agriculture with greatest economic and social importance for Brazil, demanding increased investments in technology.

In recent years, the productivity of cotton cultivation has increased due to genetic advances and improvements in the production system; however, this productivity could be even better if pests and diseases did not affect the crop. The fungus Fusarium oxysporum f. sp. vasinfectum, causal agent of Fusarium wilt, which is an aggressive pathogen and can cause significant productivity losses in infested areas when conditions are favorable (Cia \& Salgado, 2005; Davis et al., 2006; Amorim et al., 2011). All cultivated cotton species host the fungus, but there may be variations in virulence, depending on the cultivar. Unlike most specialized forms, it may have alternative hosts, such as species belonging to the Malvaceae, Solanaceae, and Leguminosae families (Assigbetse et al., 1994). 
No cultivars are highly resistant to Fusarium wilt, which makes it difficult to control. However, some procedures are important to manage this pathogen in the field, such as crop rotation and the adoption of the exclusion principle, to prevent the entry of the pathogen in non-contaminated areas. In this context, the use of pathogen-free (certified) seeds and the chemical treatment of seeds are essential for successful management (Beltrão, 1999; Cia et al., 1999).

The chemical control of plant diseases is constantly the only efficient and viable measure to guarantee high productivity and production quality when the pathogen already exists in the production field (Asif et al., 2020). Varieties of plants that are interesting, due to their good agronomic performance and consumer preference, generally have a certain vulnerability to phytopathogenic agents, and the cotton culture suffers from this problem. Thus, the use of systemic or contact chemicals for pest control is widely used in this crop. This intervention is carried out mainly before the plants reach the field (seed treatment), followed by successive applications with various other products and can greatly increase production costs, due to the large volume of pesticides employed and the high prices of these products. Thus, economically advantageous alternatives for the farmer that are also less aggressive to the environment are clearly needed (Bennett et al., 2011).

In this context, biological control has been identified as a safe method to manage diseases of cultivated plants (Punja \& Utkhede, 2003), presenting numerous advantages in relation to chemical control, since with the use of antagonists (fungi, viruses, bacteria, and others) biological control is easy to apply, less expensive, and does not harm the environment or humans (Soares \& Santos, 2006; Farias et al., 2019).

Among the innumerable natural enemies identified as biological control agents, a wide range of rhizosphere bacteria exert an antagonistic effect to phytopathogens (Sturz \& Nowak, 2000; Tian et al., 2007; Machado et al., 2012). These bacteria can survive in the rhizosphere, colonizing the roots of plants to provide several benefits, such as growth promotion, availability of plant nutrients and hormones, protection against pathogens, and greater drought resistance. Such bacteria are also known as Plant Growth-Promoting Rhizobacteria (PGPR) (Liu et al., 2017; Calvo et al., 2019).

PGPR can act as biological control agents mainly for the production of bactericidal, fungicidal, or mycostatic substances, by inhibiting the growth and development of pathogenic agents (Jiao et al., 2021) through the production of antibiotics, toxins, and enzymes; interfering in the plant-host recognition process; and inducing resistance and/or providing healthy plant development (Tian et al., 2007; Farias et al., 2019). Hence, the present study aimed to select strains of Bacillus spp. whose metabolites are toxic to F. oxysporum from tests under laboratory and greenhouse conditions.

\section{Material and Methods}

\subsection{Selection of Culture Medium for Tests With Fusarium oxysporum}

Before conducting the antagonism tests, a culture medium was sought that was favorable to potential antagonists but also does not harm the pathogen, to achieve a balance close to the ideal for both. Therefore, different combinations of culture media were tested in the cultivation of Bacillus and Fusarium. The tested media combined potato dextrose agar (PDA) and Embrapa medium (EM) at proportions of PDA 100\%; PDA 75\% plus EM $25 \%$; PDA $50 \%$ plus EM $50 \%$; PDA $25 \%$ plus EM $75 \%$; PDA $100 \%$ plus EM $100 \%$; and $100 \%$ EM (Table $1)$.

Table 1. Quantity ( $\mathrm{g}$ ) of reagents used in $1 \mathrm{~L}$ of distilled water in culture media

\begin{tabular}{lllllll}
\hline Reagents* & PDA Himedia & Nutrient Broth & Yeast Extract & $\mathrm{KH}_{2} \mathrm{PO}_{4}$ & Agar & MS (mL) \\
\hline PDA 100\% & 39.00 & 0.00 & 0.00 & 0.00 & 0.00 & 0.00 \\
PDA 75\% + EM 25\% & 29.25 & 6.00 & 0.25 & 0.25 & 3.50 & 2.50 \\
PDA 50\% + EM 50\% & 19.50 & 4.00 & 0.50 & 0.50 & 7.00 & 5.00 \\
PDA 25\% + EM 75\% & 9.75 & 2.00 & 0.75 & 0.75 & 10.50 & 7.50 \\
PDA 100\%+ EM 100\% & 39.00 & 8.00 & 1.00 & 1.00 & 0.00 & 10.00 \\
EM 100\% & 0.00 & 8.00 & 1.00 & 1.00 & 14.00 & 10.00 \\
\hline
\end{tabular}

Note. ${ }^{*} \mathrm{pH} 7.0$ for all media; Nutrient broth (Composition of $13.0 \mathrm{~g}$ of the commercial product $=$ beef extract 1.0 $\mathrm{g}$; yeast extract-2.0 g; peptone $-5.0 \mathrm{~g}$; sodium chloride $-5.0 \mathrm{~g}$ ); $\mathrm{MS}=$ Mineral salts (Composition $=10 \mathrm{~g}$ $\mathrm{CaCO}_{3}, 10 \mathrm{~g} \mathrm{MgSO}_{4} \cdot 7 \mathrm{H}_{2} \mathrm{O}, 1 \mathrm{~g} \mathrm{FeSO}_{4} \cdot 7 \mathrm{H}_{2} \mathrm{O}, 1 \mathrm{~g} \mathrm{MnSO}_{4}, 1 \mathrm{~g} \mathrm{ZnSO}{ }_{4} \cdot 7 \mathrm{H}_{2} \mathrm{O}, 1 \mathrm{~L}$ distilled water). 


\subsection{Preparation of the Plates}

After autoclaving, the hot culture media were taken to a laminar flow chamber and poured into Petri dishes. After cooling (gelling), they were sealed with plastic film, identified, and stored in an incubator at $28{ }^{\circ} \mathrm{C}\left( \pm 2{ }^{\circ} \mathrm{C}\right)$ for three days to verify contamination.

The treatments used for all combinations of culture media reagents were bacteria, fungus, and fungus plus bacteria. The incubation temperatures of 25 and $28{ }^{\circ} \mathrm{C}$ were ideal for the growth of the fungus and bacteria, respectively. Both organisms were deposited individually in the center of the dish, a $0.5 \mathrm{~cm}$ PDA disk containing mycelium of the fungus or $10 \mu \mathrm{L}$ of bacterial suspension. The evaluations were carried out nine days after the beginning of the tests.

\subsection{Bacillus antagonism to Fusarium oxysporum f. sp. vasinfectum}

The evaluation of Bacillus antagonism to F. oxysporum f. sp. vasinfectum (strains provided by Embrapa Cotton) was carried out through direct confrontation, with the adoption of the method of dual culture in Petri dishes, according to Dennis \& Webster (1971b), with adaptations. The 178 strains of Bacillus spp. tested were deposited in the Collection of Entomopathogenic Bacteria at Embrapa Genetic Resources and Biotechnology. The strains were inoculated in Embrapa liquid medium and after inoculation were placed in a rotary incubator (150 $\mathrm{rpm} / \mathrm{min}$ ), in the absence of light, at $28 \pm 2{ }^{\circ} \mathrm{C}$ for $72 \mathrm{~h}$. The isolate of the pathogen was initially multiplied in dishes containing the PDA culture medium, placed in an incubator at $25 \pm 2{ }^{\circ} \mathrm{C}$ and a 12-hour photophase for 9 days. Agar discs $(0.5 \mathrm{~cm}$ in diameter) containing fungal structure taken from the pure culture of the pathogen were deposited in the central region of the dishes containing the medium previously selected for this test (PDA medium + Embrapa medium), and the antagonist was applied in four points of the dish in $10 \mu \mathrm{L}$ aliquots, so that they were equidistant and approximately $1 \mathrm{~cm}$ from the edge of the Petri dish. Then, the dishes were sealed with plastic film and immediately placed in an incubator with the same conditions described for the growth of the fungus. As a control, dishes with PDA + Embrapa medium were prepared, containing the pathogen inoculated in the center of the dish as described for the bioassay and instead of inoculating bacterial suspensions, as in the treatments, only pure Embrapa liquid medium was applied in the same amounts described for the treatments (10 $\mu \mathrm{L}$ ). For each treatment including controls, four repetitions were performed. A grading scale (in sequence) was used for evaluations, at nine days of culture, when the colonies of the control dishes, containing only the pathogen, completely covered the surface of the culture medium, extending throughout the Petri dishes.

The structures of the confrontation zones between the two organisms were analyzed using an optical microscope with a $40 \times$ magnification. For this purpose, slides containing fragments of these confrontation zones between the fungus and the bacteria were made to observe the presence of plasmolysis of hyphae and the structural changes of these hyphae.

\subsection{Competition Test Evaluation Scale}

To evaluation the competition assay, an illustrated grading scale was proposed (Figure 1). This scale took into account variables that occurred during the development of the pathogen colony on the dish. Figures identified with the letter "A" represent the colonies that did not suffer interference from the antagonist during the test period. Figures identified with the letter "B" represent the colonies that suffered interference from the antagonist, deforming the shape of their colony.

With this scale, we assigned six different grades during the evaluations, between zero and five, thus facilitating later identification of strains with good or bad antagonistic potential for the laboratory conditions in which the assays were conducted.

\subsection{Evaluation of the Effect of Non-volatile Metabolites}

Tests with the antagonists were also carried out to evaluate the growth inhibition of the pathogen by non-volatile metabolites, based on the methodology described by Agrawal et al. (1977), with modifications. The thirteen best strains obtained in the antagonism test (S662, S685, S1301, S1600, S1809, S1823, S1875, S1967, S2535, S2536, S2538, GF266, and GF267) were grown in $50 \mathrm{~mL}$ Erlenmeyer flasks containing $15 \mathrm{~mL}$ of Embrapa medium liquid (Monnerat et al., 2007). The $100 \mu \mathrm{L}$ of the bacterium/vial inoculum were taken from Bacillus cultures previously developed in three-day-old Embrapa medium. The vials were incubated in an orbital shaker (Lab-line incubator-shaker model NT 711), at $150 \mathrm{RPM}$, at $28{ }^{\circ} \mathrm{C}$, in the absence of light. After three days, the liquid part was collected by centrifugation in an Eppendorf $5804 \mathrm{R}$ centrifuge at $13416 \mathrm{G}$ for 20 mins. After centrifugation, the supernatant was taken to a sterile environment and filtered through cellulose membranes $(0.45 \mu \mathrm{m})$. The metabolite thus sterilized was incorporated into the autoclaved PDA medium, adding $25 \%$ of the normal amount of agar, in the proportion of $25 \%(\mathrm{v} / \mathrm{v})$. For each Bacillus strain, four dishes were prepared with filtrate, for a 
total of 44 dishes. A culture disc of the pathogen was placed in the center for the dishes containing the received medium, and the dishes were then incubated at $25^{\circ} \mathrm{C}$.

The control consisted of dishes containing PDA medium, plus $25 \%$ of the normal amount of agar and incorporated $25 \%$ of pure Embrapa medium, inoculated with pathogen discs. The measurements of radial growth were taken daily until the control colony took over the entire surface of the medium.

The obtained data were submitted to ANOVA and the means compared by the Tukey test $(\mathrm{P} \leq 0.05)$, using the program Sisvar.

\subsection{Fusarium oxysporum and Bacillus interaction Under Scanning Electron Microscope}

The scanning electron microscopy (SEM) technique was employed to view details about the interaction between Bacillus strains and the pathogen, where samples from the confrontation zones between pathogen and antagonist were treated to take the images. Disks of culture medium $(5 \mathrm{~mm}$ in diameter) from confrontation zones between the colonies of Bacillus and the pathogen (F. oxysporum) were removed and subjected to the methodology described by Bossola and Russel (1998), adapted by Alves (2004), in which treatment with fixing solution (2\% gluta-raldehyde and $2 \%$ paraformaldehyde, in $0.05 \mathrm{M}$ cacodylate buffer at $\mathrm{pH} 7.2$ ) was performed at $4{ }^{\circ} \mathrm{C}$ for 24 hours, followed by 4 washes with cacodylate buffer $0.05 \mathrm{M}(\mathrm{pH} 7.2)$, and post-fixed for 1 hour at $4{ }^{\circ} \mathrm{C}$ with osmium tetroxide $\left(\mathrm{OsO}_{4}\right) 1 \%$ in $0.01 \mathrm{M}$ cacodylate buffer $(\mathrm{pH} 7.2)$.

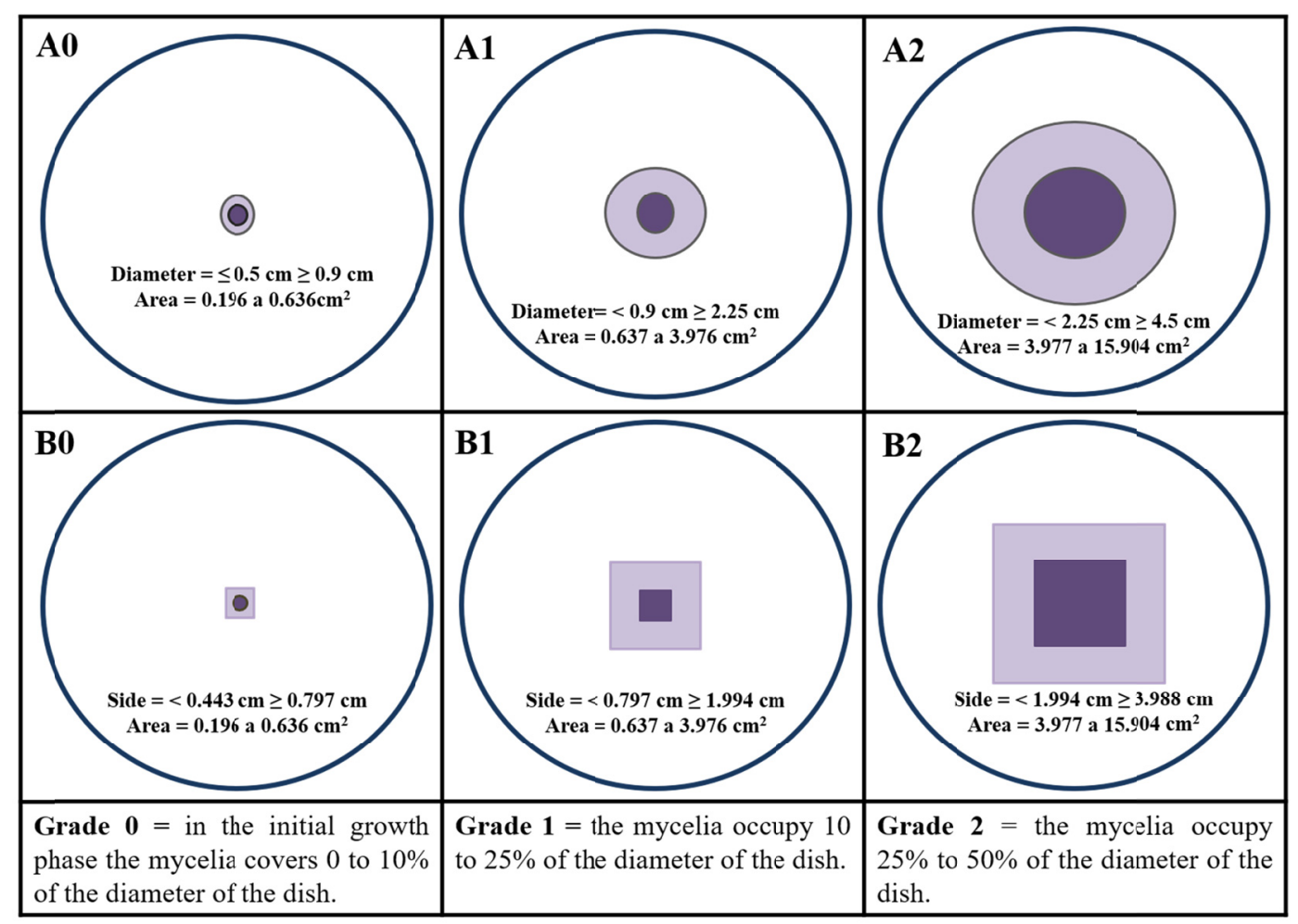




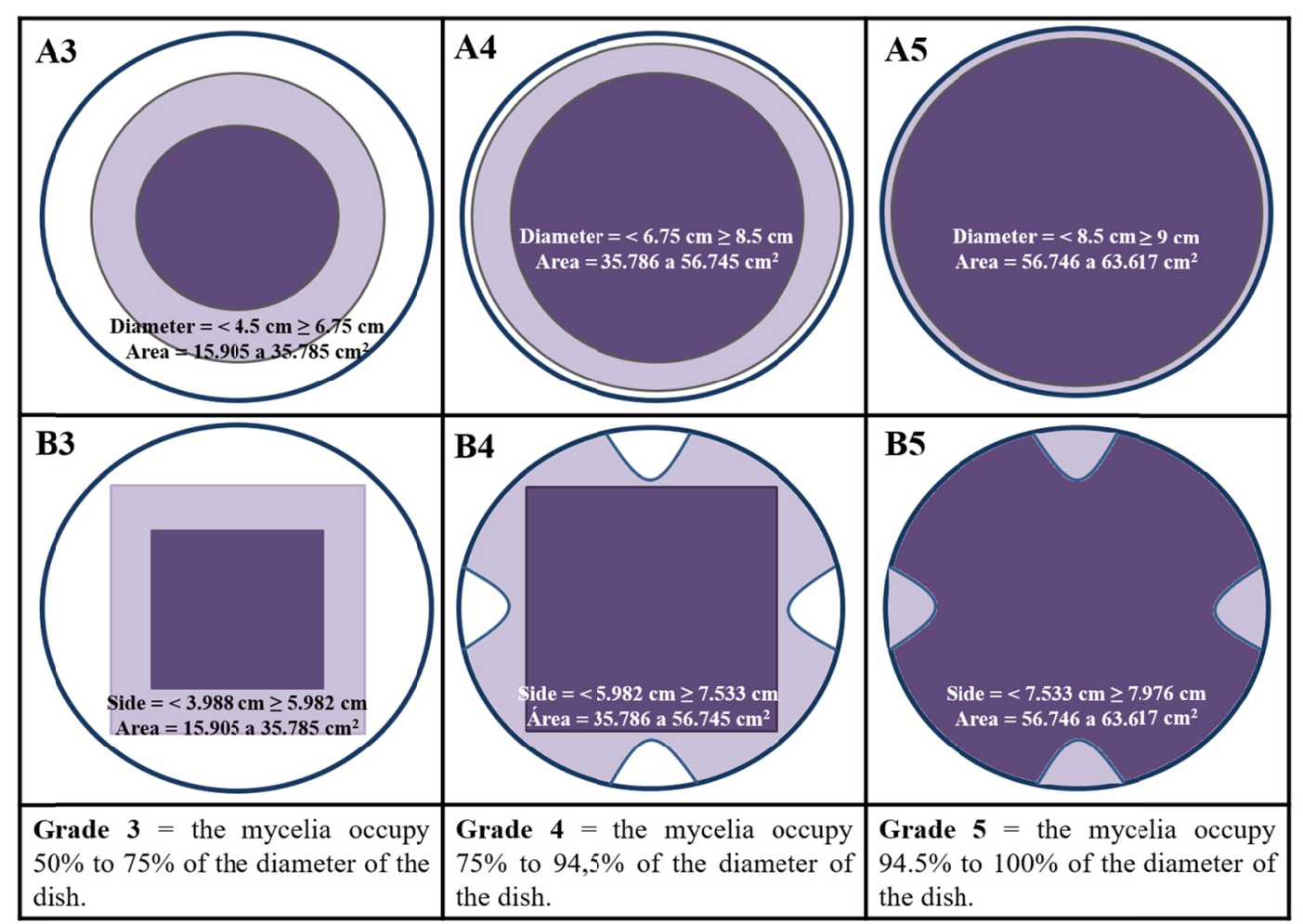

Figure 1. Growth of fungal colonies in a dual assay. Figures from A0 to A5 indicate fungal growth without interference from the antagonist. Figures B0 to B5 show growth with interference from the antagonist

The samples were then washed three times with distilled water and dehydrated in an increasing gradient of acetone $(30,50,70,80,90$, and twice in $100 \%)$. To dry the critical point, carbon dioxide was used in the Elmitech Critical Point Drayer K850 dryer. The supports containing the material were metallized with gold, using a $25 \mathrm{~mA}$ current, in an air atmosphere of 1.10-2 mbar for 2'30”. The images were obtained at the Scanning Electron Microscopy Laboratory of the Institute of Biological Sciences at the University of Brasília. The slides were viewed with the JEOL JSM-700 $1 \mathrm{~F}$ electron microscope. Micrographs were taken of changes indicative of toxicity.

\subsection{Evaluation of the Effect of Volatile Metabolites}

To assess the effect of volatile metabolites from Bacillus spp. on F. oxysporum f. sp. vasinfectum tests were conducted using the modified method of Dennis and Webster (1971a), with the thirteen best strains obtained in the dual test. Two Petri dish were used to assemble each sample unit, one containing PDA culture medium received an agar disc $(5 \mathrm{~mm})$ removed from the pathogen colony, and the other dish containing Embrapa culture medium inoculated with $40 \mu \mathrm{L}$ of suspension with the antagonist which was spread on the surface of the medium using a glass spreader. After inoculation, the bases containing the antagonist and the pathogen were joined and sealed with PVC film, to prevent the escape of volatile metabolites. The experimental units, now formed by two dish bases, with the lower base inoculated with the pathogen, were kept under the same incubation conditions. As a control, a base containing the pathogen and another containing only Embrapa medium were joined without inoculation of the antagonist. Mycelial growth was evaluated daily in all dishes until the control covered the entire surface of the medium.

The adopted experimental design was completely randomized with four replications and the experimental units consisted of two dish bottoms joined with plastic film. This experiment was performed twice.

\subsection{Multiplication of Fusarium sp. in Rice}

The multiplication of Fusarium for the experiment was carried out according to a methodology adapted from Serra and Silva (2005), where $300 \mathrm{~g}$ of parboiled rice were packaged in autoclavable plastic bags, moistened with distilled water at $60 \%$ of the weight $(180 \mathrm{~mL})$, for each bag. The substrate thus prepared was autoclaved at $120^{\circ} \mathrm{C}$ for $20 \mathrm{~min}$. Five discs $(0.5 \mathrm{~cm})$ of PDA containing mycelium of the pathogen, which had been incubated 
for 9 days at $25 \pm 2{ }^{\circ} \mathrm{C}$ and $12 \mathrm{~h}$ dark/light, were used to inoculate the substrate. The plastic bags containing the inoculated substrate were also kept at $25 \pm 2{ }^{\circ} \mathrm{C}$ and $12 \mathrm{~h}$ photophase, for 15 days. Every two days, the packages were gently manipulated to homogenize the fungus mycelium on the rice substrate.

\subsection{Production of Bacillus Suspension}

The 13 bacteria selected in the dual culture were multiplied to perform an in vivo assay in a greenhouse with cotton. The inoculants preserved on strips of paper, in a sterile environment, were placed in Erlenmeyer flask $(150 \mathrm{~mL})$ containing $50 \mathrm{~mL}$ of Embrapa medium (Monnerat et al., 2007). After inoculation in the flasks, they were placed in a rotary incubator $(150 \mathrm{rpm})$, at $28 \pm 2{ }^{\circ} \mathrm{C}$ in the absence of light for $72 \mathrm{~h}$. After this incubation period, bacterial suspensions were ready for use in the assay.

\subsection{Cotton Germination Test on Substrate With Fusarium}

For this assay, plastic trays with volumetric capacity of three liters with dimensions of $30.3 \mathrm{~cm}$ (length) $\times 22.1$ $\mathrm{cm}$ (width) $\times 7.5 \mathrm{~cm}$ (height) were purchased. These trays were filled with a mixture of soil and autoclaved substrate. After autoclaving, the soil and substrate were taken to a greenhouse where they were mixed and stored in a container until the installation of the experiment.

\subsection{Preparation of Cotton Seeds}

The cotton variety FM 966, which is susceptible to F. oxysporum f. sp. vasinfectum, was used. After selection of the variety, the seeds provided by IMA (Instituto Mato-grossense do Cotton) were superficially disinfected with $1 \%$ hypochlorite $/ 1 \mathrm{~min} ; 70 \%$ alcohol/ $1 \mathrm{~min}$, and twice in distilled water $/ 1 \mathrm{~min}$.

\subsection{Greenhouse Assay}

The treatments for the greenhouse test were: (1) untreated control; (2) control with autoclaved Fusarium; (3) control with active Fusarium; (4) chemical control (Derosal Plus) + Fusarium; (5) treatments with bacteria + Fusarium.

After superficial disinfection, the seeds for the treatments with the active Fusarium were weighed and that exact weight of parboiled rice with Fusarium (not autoclaved) was added. After the addition of the fungus, the cotton seeds were placed in a tray and homogenized so that the surface of the cotton seeds was covered with pathogen structures.

In the greenhouse, the plastic trays were identified and placed on benches. Then the trays were filled with a layer of approximately four centimeters of the substrate. On this layer, the seeds treated and not treated with the pathogen were arranged in four rows (three rows of six seeds and one row of seven seeds). The seeds, placed on the soil surface, were inoculated with biological treatments of $250 \mu \mathrm{L}$ bacterial suspension for each the tray according to the appropriate groups. The chemical treatment (for this group) was carried out before inoculation of the pathogen following the dosage recommended by the manufacturer. After the placement of the seeds in each of the trays and the inoculations carried out according to their treatment groups, another layer of substrate of about three centimeters was placed on top to cover the seeds. The first irrigation was carried out right after planting.

This experiment was conducted for 30 days, and after the beginning of germination, was inspected every day. In this experiment, the number of germinated healthy and sick plants as well as the number of wilted (plant death after germination) were evaluated. The plants were irrigated every two days and no phytosanitary products were required during this experiment.

The adopted experimental design was completely randomized with five replicates per treatment. Each experimental unit was composed of a tray containing 25 seeds. The data obtained from the evaluation of all treatments were subjected to analysis of variance and the means compared by Tukey's test at $5 \%$ probability, using the statistical program Sisvar.

\section{Results and Discussion}

\subsection{Selection of Culture Medium for Tests With Fusarium oxysporum}

Variations in the growth of the two organisms (Bacillus and Fusarium oxysporum) were found due to the different concentrations of the culture media used (Figure 2). 


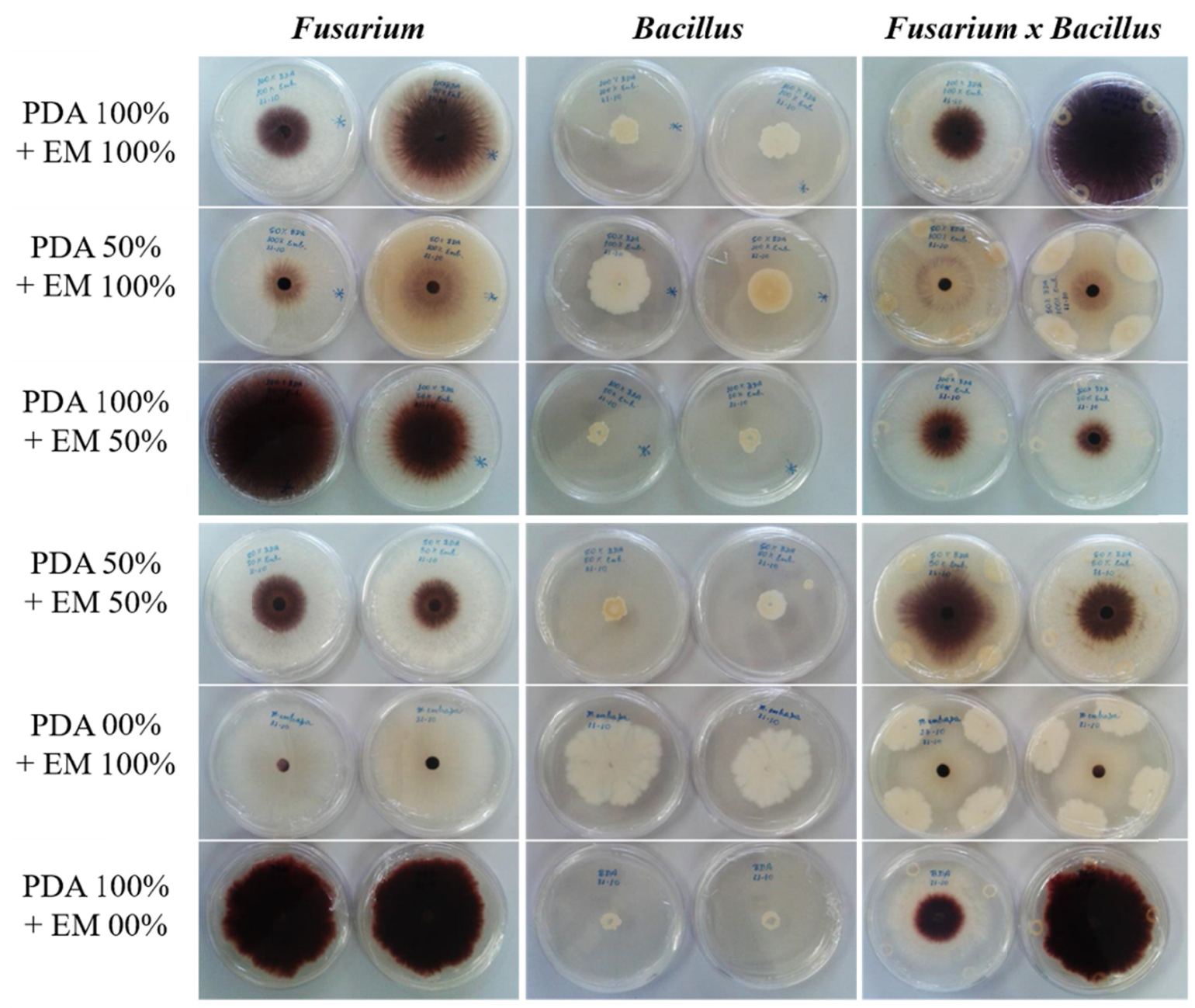

Figure 2. Growth evaluation of Fusarium oxysporum and Bacillus sp. in combinations of culture media with different concentrations of reagents

The best proportion of reagents for a neutral culture was PDA $100 \%+$ EM100\%, which provided balanced growth without harming or favoring any organism.

\subsection{Evaluation Scale for the Competition Assay}

Although the literature contains several grading scales, the proposed scale that we assembled for this assay was appropriate for our evaluations. An advantage of this scale is the ease of classifying a strain, because with the two standards presented, the evaluator is less apt to make errors and the results will be more precise.

The criterion chosen to classify the colonies was the percentage of the diameter of the Petri dish, which makes it easier to determine the grades and limits reading errors. In addition, when these data are transformed from diameter to area $\left(\mathrm{cm}^{2}\right)$ (Table 2), the differences become more obvious, providing more consistency to the results. However, if the area instead of the diameter had been used, the visual differences would have been almost imperceptible from one grade to another, inducing more evaluator error. 
Table 2. Values of the proposed grading scale in percentage of the total diameter, diameter in centimeters, area of the colony in square centimeters, maximum percentage occupied by the colony for each of the grades, and values of the intervals between the grades in square centimeters of area and percentage of the total area

\begin{tabular}{lllllll}
\hline Grade & $\begin{array}{l}\text { Diameter of } \\
\text { the colony }(\%)\end{array}$ & $\begin{array}{l}\text { Diameter of } \\
\text { the colony }(\mathrm{cm})\end{array}$ & $\begin{array}{l}\text { Area of the } \\
\text { colony }\left(\mathrm{cm}^{2}\right)\end{array}$ & $\begin{array}{l}\text { Area Diameter of } \\
\text { the colony }(\%)\end{array}$ & $\begin{array}{l}\text { Area of grade } \\
\text { range }\left(\mathrm{cm}^{2}\right)\end{array}$ & $\begin{array}{l}\text { Area of grade } \\
\text { range }(\%)\end{array}$ \\
\hline 0 & 10 & 0.9 & 0.636 & 1 & 0.636 & 1 \\
1 & 25 & 2.25 & 3.976 & 6.25 & 3.340 & 5.25 \\
2 & 50 & 4.5 & 15.904 & 25 & 11.928 & 18.75 \\
3 & 75 & 6.75 & 35.785 & 56.251 & 19.881 & 31.25 \\
4 & 94.5 & 8.5 & 56.745 & 89.198 & 20.960 & 32.947 \\
5 & 100 & 9 & 63.617 & 100 & 6.872 & 10.802 \\
\hline
\end{tabular}

\subsection{Evaluation of the Antagonism of Bacillus spp. Against Fusarium oxysporum f. sp. vasinfectum in Dual Cultivation}

In this assay, the antagonistic potential of 178 strains of Bacillus sp. against Fusarium oxysporum f. sp. vasinfectum was evaluated according to the grading scale proposed in this work. For instance, the results (Figure 1) allow better understanding of how the readings were performed, and the strains that achieved grades between zero to two were selected for further tests. Based on this principle, 13 strains with good in vitro control potential were selected.

No strain achieved a grade of $0 ; 2$ received grade 1; 10 scored 2; 26 had grade 3;24 scored 4; and the rest of the strains (115) did not present antagonistic activity to the pathogen (Table 3).

Table 3. Percentage of Bacillus strains within the grading scale employed in the study (178 strains evaluated)

\begin{tabular}{ll}
\hline Grades & $\%$ of isolates \\
\hline 0 & 0.00 \\
1 & 1.12 \\
2 & 5.62 \\
3 & 14.61 \\
4 & 13.48 \\
5 & 64.61 \\
\hline
\end{tabular}

Chaurasia et al. (2005), working with strains of B. subtilis isolated from the plant rhizosphere, managed to control the mycelial growth of six species of fungi including four plant pathogens, Alternaria alternata, Cladosporium oxysporum, Fusarium oxysporum, and Paecilomyces lilacinus. In laboratory tests, this effect was noticeable in dual culture. In subsequent assays of volatile and water-soluble metabolites, these authors concluded that the toxic effects of volatile metabolites were superior causing greater damage to the pathogen with alterations and deformation in mycelium and conidia.

Gupta and Vakhlu (2015), using the same techniques employed in this work, searched for biocontrol agents against $F$. oxysporum in saffron (Crocus sativus). They isolated 400 bacterial strains from an area producing of this spice. Then, these authors performed in vitro assays (dual and soluble metabolites) to select antagonistic strains for subsequent in vivo testing. With these first assays, they selected the bacterium $B$. amyloliquefaciens that had an antagonistic effect to $F$. oxysporum, and the greenhouse tests confirmed the potential of the selected organism.

Scanning electron microscope (SEM) of the confrontation zones between the pathogen and antagonist showed deformed hyphae of the pathogen, with the conglobation, hydrolysis, and dead hyphae due to the toxic action of the metabolites from the antagonist (Figure 3). These images proved the toxic effect of Bacillus isolates on Fusarium oxysporum. The results on the toxic effect of Bacillus metabolites on Fusarium corroborate with those obtained by Gong et al. (2015), who worked with three classes of cyclic lipopeptides, produced by Bacillus amyloliquefaciens and verified their effect on the pathogen Fusarium graminearum. These authors obtained two compounds isolated from reverse-phase high-performance liquid chromatography and electrospray ionization-mass spectrometry. These products obtained, when tested on the pathogen under laboratory conditions, 
had a toxic effect, in which serious morphological changes in conidia and substantial distortions in hyphae were observed with the aid of microscopy techniques, as seen in our assay.

\subsection{Evaluation of the Inhibitory Effect of Non-volatile Metabolites Produced by Bacillus spp.}

The metabolite of some strains (GF267, S1301, S1823, S1967, S2535, and S2536) had a toxic effect on the development of the pathogen colony at some point during the assay. This effect was noticed beginning on the fifth day of evaluation when significant statistical differences were observed between the growth of the normal colony of the pathogen (control) compared to colonies of some treatments. This effect was most frequent between the seventh and eighth day of the evaluations, with a greatest number of treatments affecting the growth of the pathogen. However, this effect was only maintained until the end of the trial by four strains, S1301, S1967, S2535 and S2536, which provided $12.92 \%, 27.31 \%, 33.06 \%$, and $30.43 \%$ control at the end of the experiment, respectively (Table 4 ).

Table 4. Effect of non-volatile metabolites of Bacillus performed every 24 hours on the area $\left(\mathrm{cm}^{2}\right)$ of the Fusarium colony

\begin{tabular}{llllllllll}
\hline Strain & $1^{\text {st }}$ & $2^{\text {nd }}$ & $3^{\text {rd }}$ & $4^{\text {th }}$ & $5^{\text {th }}$ & $6^{\text {th }}$ & $7^{\text {th }}$ & $8^{\text {th }}$ & $9^{\text {th }}$ \\
\hline GF266 & $0.4 \mathrm{aF}$ & $1.3 \mathrm{aF}$ & $5.2 \mathrm{aF}$ & $11.7 \mathrm{abcE}$ & $20.5 \mathrm{abcD}$ & $29.5 \mathrm{bcC}$ & $41.1 \mathrm{bB}$ & $53.1 \mathrm{aA}$ & $56.8 \mathrm{aA}$ \\
$\mathrm{GF} 267$ & $0.4 \mathrm{aG}$ & $1.4 \mathrm{aG}$ & $5.5 \mathrm{aFG}$ & $11.0 \mathrm{abcF}$ & $17.8 \mathrm{bcdE}$ & $25.1 \mathrm{cdD}$ & $33.7 \mathrm{cC}$ & $42.8 \mathrm{bB}$ & $52.4 \mathrm{abA}$ \\
$\mathrm{S} 662$ & $0.4 \mathrm{aG}$ & $1.6 \mathrm{aFG}$ & $6.5 \mathrm{aF}$ & $13.0 \mathrm{abE}$ & $22.1 \mathrm{abD}$ & $31.2 \mathrm{bcC}$ & $41.8 \mathrm{bB}$ & $51.4 \mathrm{aA}$ & $56.8 \mathrm{aA}$ \\
$\mathrm{S} 685$ & $0.4 \mathrm{aG}$ & $1.5 \mathrm{aFG}$ & $6.5 \mathrm{aF}$ & $13.5 \mathrm{abE}$ & $22.8 \mathrm{abD}$ & $32.8 \mathrm{abC}$ & $43.4 \mathrm{bB}$ & $52.8 \mathrm{aA}$ & $56.8 \mathrm{aA}$ \\
$\mathrm{S} 1301$ & $0.4 \mathrm{aG}$ & $1.4 \mathrm{aG}$ & $4.5 \mathrm{aFG}$ & $8.7 \mathrm{abcF}$ & $14.7 \mathrm{cdE}$ & $21.9 \mathrm{deD}$ & $29.1 \mathrm{cdC}$ & $38.4 \mathrm{bcB}$ & $49.4 \mathrm{bA}$ \\
$\mathrm{S} 1600$ & $0.4 \mathrm{aG}$ & $1.7 \mathrm{aFG}$ & $6.9 \mathrm{aF}$ & $14.1 \mathrm{abE}$ & $23.4 \mathrm{abD}$ & $34.5 \mathrm{abC}$ & $45.1 \mathrm{bB}$ & $56.8 \mathrm{aA}$ & $56.8 \mathrm{aA}$ \\
$\mathrm{S} 1809$ & $0.4 \mathrm{aG}$ & $1.7 \mathrm{aFG}$ & $6.8 \mathrm{aF}$ & $13.9 \mathrm{abE}$ & $23.2 \mathrm{abD}$ & $32.3 \mathrm{abC}$ & $42.1 \mathrm{bB}$ & $52.2 \mathrm{aA}$ & $56.8 \mathrm{aA}$ \\
$\mathrm{S} 1823$ & $0.4 \mathrm{aG}$ & $1.0 \mathrm{aFG}$ & $4.0 \mathrm{aFG}$ & $6.6 \mathrm{cF}$ & $13.5 \mathrm{dE}$ & $22.8 \mathrm{deD}$ & $32.8 \mathrm{cC}$ & $43.4 \mathrm{bB}$ & $52.8 \mathrm{abA}$ \\
$\mathrm{S} 1875$ & $0.4 \mathrm{aG}$ & $1.6 \mathrm{aFG}$ & $6.6 \mathrm{aF}$ & $13.9 \mathrm{abE}$ & $23.9 \mathrm{abD}$ & $34.5 \mathrm{abC}$ & $46.5 \mathrm{abB}$ & $55.8 \mathrm{aA}$ & $56.8 \mathrm{aA}$ \\
$\mathrm{S} 1967$ & $0.4 \mathrm{aG}$ & $1.5 \mathrm{aG}$ & $5.3 \mathrm{aFG}$ & $9.2 \mathrm{abcEF}$ & $14.0 \mathrm{dDE}$ & $19.3 \mathrm{deD}$ & $25.7 \mathrm{dC}$ & $33.7 \mathrm{cdB}$ & $41.3 \mathrm{cA}$ \\
$\mathrm{S} 2535$ & $0.4 \mathrm{aG}$ & $1.1 \mathrm{aG}$ & $4.2 \mathrm{aFG}$ & $8.2 \mathrm{bcEF}$ & $13.0 \mathrm{dDE}$ & $18.3 \mathrm{eD}$ & $24.9 \mathrm{dC}$ & $31.4 \mathrm{~dB}$ & $38.0 \mathrm{cA}$ \\
S2536 & $0.4 \mathrm{aG}$ & $1.1 \mathrm{aG}$ & $4.2 \mathrm{aFG}$ & $8.0 \mathrm{bcEF}$ & $13.3 \mathrm{dE}$ & $19.6 \mathrm{deD}$ & $25.8 \mathrm{dC}$ & $32.2 \mathrm{~dB}$ & $39.5 \mathrm{cA}$ \\
S2538 & $0.4 \mathrm{aF}$ & $1.7 \mathrm{aEF}$ & $7.1 \mathrm{aE}$ & $14.8 \mathrm{aD}$ & $25.7 \mathrm{aC}$ & $38.2 \mathrm{aB}$ & $52.2 \mathrm{aA}$ & $56.8 \mathrm{aA}$ & $56.8 \mathrm{aA}$ \\
Control & $0.4 \mathrm{aF}$ & $1.5 \mathrm{aF}$ & $5.9 \mathrm{aF}$ & $12.2 \mathrm{abcE}$ & $20.9 \mathrm{abcD}$ & $30.2 \mathrm{bcC}$ & $41.8 \mathrm{bB}$ & $53.0 \mathrm{aA}$ & $56.8 \mathrm{aA}$ \\
\hline Note. Th & & & &
\end{tabular}

Note. The means followed by the same letter do not differ statistically. Tukey's test was applied at the $1 \%$ probability level. Comparisons within the same column, lowercase letters; comparisons within the same line, capital letters. CV: $11.56 \%$.

With these results, the metabolite of strains S1967, S2535, and S2536 had a reducing effect on the development of the pathogen from $27.31 \%$ to up to $33.06 \%$. This implies the existence of some water-soluble compound, produced by these Bacillus strains, which affects Fusarium, preventing its normal development as compared to the control.

Further studies should be conducted on this interaction, because our evidence indicates that Bacillus produces a compound that acts against the development of the $F$. oxysporum colony. The quantification and identification of this produced compound can help in the search for new tools to control the pathogen.

Romero et al. (2007) working with Bacillus subtilis to control Podosphaera fusca in melon, to elucidate the mechanism of action of this antagonist. They identified the toxic action of the supernatant produced by the bacteria on the pathogen, isolating and identified the compounds (antibiotics) present in the supernatant that are responsible for the toxic action. Based on this identification, they silenced the gene responsible for the production of this antibiotic, which interrupted its production by the bacteria, resulting in a non-control of the pathogen by the mutant bacterium. Therefore, these authors concluded that these blocked polypeptides have an important role in the antagonism of B. subtilis against $P$. fusca. This work demonstrates the importance of secondary metabolites on the relationships between antagonist and pathogen.

Crane et al. (2013) examined the inhibitory effect of B. amyloliquefaciens on Fusarium in wheat under laboratory conditions. They attributed this effect to the secondary metabolites (antibiotics) produced by the bacterium, because when the same treatment was applied in field conditions, the antagonist was unable to control 
the pathogen even if the bacteria was present in the soil. The authors monitored the concentration of the antibiotic produced by the bacterium and confirmed that it only persisted in the soil for a maximum of three days, and after that time, its concentration was practically zero, making the control of the pathogen impossible. With the study, the researchers concluded that this effect is due to the presence of iturin and its concentration must be maintained at high levels to control the disease during the infectious period of the pathogen.

To elucidate the action of Bacillus sp., Patel et al. (2011) studied the action of secondary compounds produced by this organism on the permeability of the fungal membrane. They concluded that some secondary compounds directly influence the permeability of the fungal membrane by promoting the opening of pores in the fungi membrane, causing extravasation of the cellular content of its hyphae. A similar effect was observed in the hyphae of F. oxysporum in our study (Figure $3 F$ ).

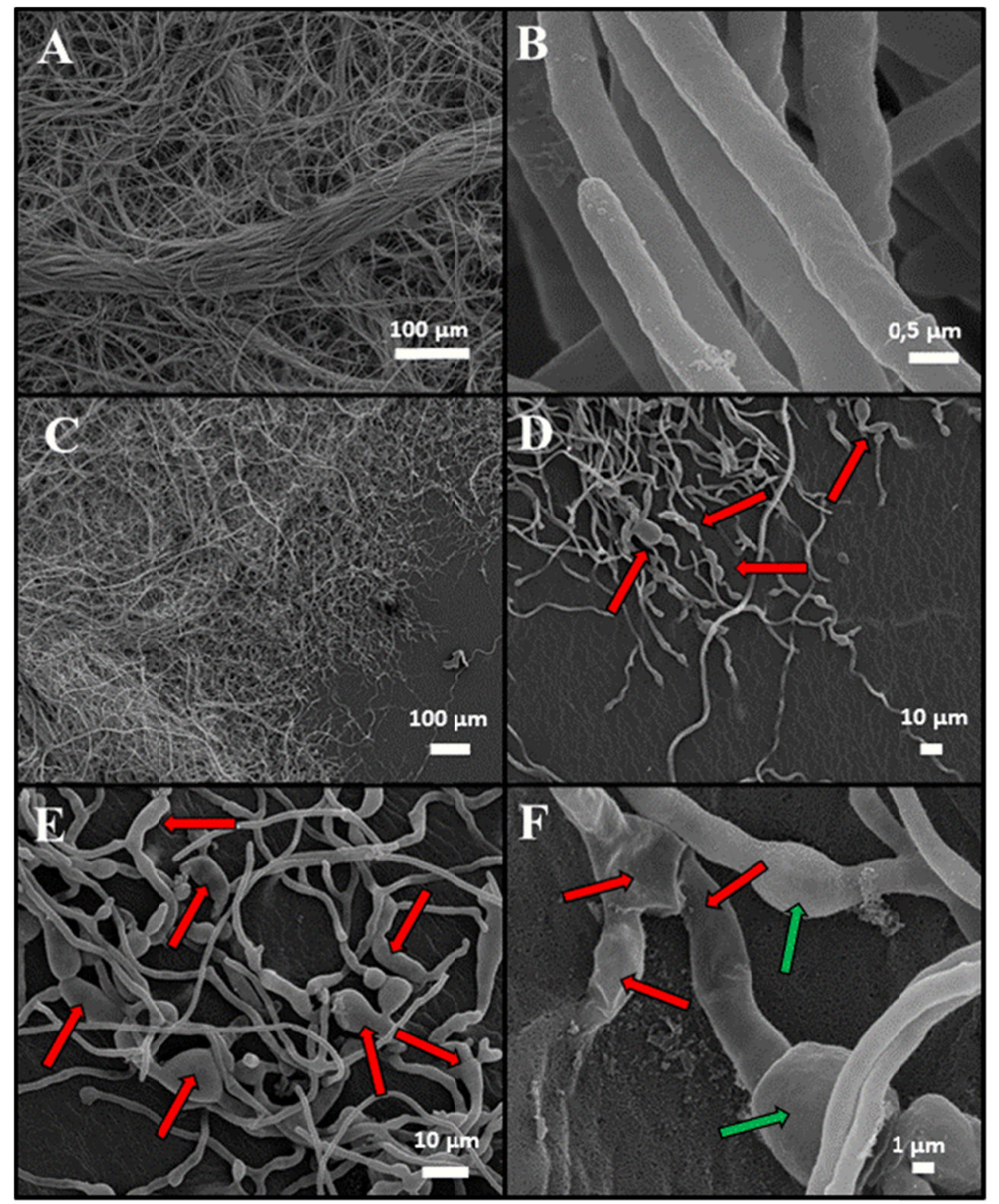

Figure 3. SEM images. A: panoramic view of the control colony of F. oxysporum; B: image of normal $F$. oxysporum hyphae from the control; $\mathrm{C}$ : panoramic view of the confrontation zones between the fungus and antagonist; D: image of the area where the fungus is confronted with soluble metabolites of the bacteria (GF266), showing various deformation points of the Fusarium hyphae indicated by the red arrows; E: Arrows indicating conglobation of Fusarium hyphae with irregular surfaces, expanded width on contact with the region of bacterial interference; and F: Red arrows indicating hydrolysis of Fusarium hyphae and green arrows indicating hyphae with expanded widths 
Abed et al. (2016), in the search for rhizobacteria antagonistic against $F$. oxysporum f. sp. ciceris in chickpea, first made an in vitro selection from 140 bacterial strains to identify those with some biocontrol potential. Then, other tests found that the water-soluble metabolites provided very promising results, identifying a bacterium ( $B$. aneurinilyticus) that inhibited up to $77 \%$ the development of the pathogen mycelium. This shows the potential of these organisms with the production of secondary compounds (Ntushelo et al., 2019). These results also demonstrate the extracellular compounds produced by bacteria are active in the control of phytopathogens, corroborating the results found in our study.

Dunlap et al. (2011), studying polypeptides in three strains of B. subtilis known to be antagonistic to Gibberella $z e a e$, verified that production of antifungal compounds in the families iturin and fengycin during the stationary growth phase. Mass spectroscopy was employed to isolate and identify these compounds, and with additional assays proved their toxic action on the fungus.

\subsection{Evaluation of the Inhibitory Effect of Volatile Metabolites Produced by Bacillus spp.}

The results proved that the tested Bacillus strains produce volatiles with antagonistic action to Fusarium (table 5). The interference by these volatiles began to be noticed on the fourth day of the assay, when they reduced the growth rate of the fungus colony. On the fifth day of evaluations, all treatments differed statistically from the control with reduced development of the pathogen colony. The cause of this action could be the competition for oxygen, because the growth peak of the Bacillus colonies was noticeable in this period. Another hypothesis to explain this could be due to the higher activity of the bacteria in the environment with a consequent increase in the production of secondary metabolites.

On the sixth day, some treatments lost their inhibitory effect, perhaps because they exhausted the nutrients in the environment. Two strains, S1823 and S2536, maintained their antagonistic effect on the fungus, from the fifth day to the last day of the assay, with control of $11.51 \%$ and $15.51 \%$, respectively. This indicates the presence of this mechanism for these strains, in addition to other mechanisms, such as the production of water-soluble metabolites, shown in the previous test for these two strains, which make them more efficient to control this phytopathogen.

In an attempt to identify rhizobacteria with biocontrol potential over $F$. oxysporum f. sp. ciceris, Abed et al. (2016) performed several tests. The volatile metabolite assay reduced the growth of the pathogen by more than $70 \%$ compared to the control using B. firmus. This indicates the potential of organisms to produce these compounds and confirms the production of these active volatiles to control phytopathogens, which corroborates with the results presented in our work.

The potential for volatile metabolites is probably due to its excellent ability to diffuse in the soil environment, through pores or water films, efficiently reaching pathogens in this environment (Lobo Júnior \& Abreu, 2000). Liu et al. (2018) demonstrated that mixtures of Bacillus strains exhibited biological control of multiple plant diseases and plant-growth promotion.

Zhang et al. (2013) isolated and identified several volatile compounds produced by Bacillus atrophaeus with antifungal activity. Compounds identified as alcohols, phenols, amines, amides, and alkane reduced the mycelial growth of Botrytis cinerea.

Arrebola et al. (2010), analyzing the effect of volatile metabolites of B. subtilis and B. amyloliquefaciens on the biological control of fungi from the genus Penicillium after the fruit harvest, achieved an inhibition of more than $73 \%$ in the mycelial growth of these pathogens by volatiles produced by B. amyloliquefaciens. They also found that although B. subtilis produces far more compounds (21 types) than B. amyloliquefaciens ( 8 types), the latter controlled the pathogen more efficiently, probably due to the greater production of ketones. The authors also observed a gradual increase in the concentration of compounds over days; for these antagonists, the greatest production was on the tenth day of cultivation.

\subsection{Greenhouse Tests}

With this germination test (Table 6), 11 treatments and the negative control (without treatment) presented statistically superior results to the positive control (only with Fusarium). This result demonstrates the destructive power of this pathogen, when present in cotton seeds, making seed germination unfeasible and breaking the stand, in this case over $70 \%$. An event similar to this could make production unfeasible if it occurred in a commercial cotton area.

The biological treatments used in this study did not differ statistically from chemical treatment, but their results were superior to that of the control. This suggests the need to expand studies in this area to enable the use of this control modality combined with other methods, to treat seeds, increasing the efficiency of control, because the 
adoption of only one method is not advisable, especially if others tools that can be combined to obtain more satisfactory results.

Table 5. Effect of volatile metabolites of Bacillus performed every 24 hours on the area $\left(\mathrm{cm}^{2}\right)$ of the Fusarium colony

\begin{tabular}{lllllllllll}
\hline Strain & $1^{\text {st }}$ & $2^{\text {nd }}$ & $3^{\text {rd }}$ & $4^{\text {th }}$ & $5^{\text {th }}$ & $6^{\text {th }}$ & $7^{\text {th }}$ & $8^{\text {th }}$ & $9^{\text {th }}$ & $10^{\text {th }}$ \\
\hline GF266 & $0.4 \mathrm{aI}$ & $1.5 \mathrm{aHI}$ & $5.0 \mathrm{aGH}$ & $8.0 \mathrm{abFG}$ & $10.1 \mathrm{bcF}$ & $19.6 \mathrm{bcdeE}$ & $28.0 \mathrm{fghD}$ & $37.7 \mathrm{efgC}$ & $45.9 \mathrm{bcB}$ & $56.4 \mathrm{aA}$ \\
$\mathrm{GF} 267$ & $0.4 \mathrm{aI}$ & $1.9 \mathrm{aHI}$ & $5.5 \mathrm{aGH}$ & $8.4 \mathrm{abFG}$ & $10.6 \mathrm{bcF}$ & $20.2 \mathrm{bcdeE}$ & $28.2 \mathrm{efghD}$ & $37.5 \mathrm{efgC}$ & $46.2 \mathrm{bB}$ & $54.0 \mathrm{abA}$ \\
$\mathrm{S} 662$ & $0.4 \mathrm{aH}$ & $1.6 \mathrm{aGH}$ & $4.7 \mathrm{aFG}$ & $6.9 \mathrm{bEF}$ & $10.0 \mathrm{bcE}$ & $22.4 \mathrm{abcD}$ & $34.6 \mathrm{abC}$ & $45.3 \mathrm{aB}$ & $56.8 \mathrm{aA}$ & $56.8 \mathrm{aA}$ \\
$\mathrm{S} 685$ & $0.4 \mathrm{aG}$ & $1.8 \mathrm{aG}$ & $5.6 \mathrm{aF}$ & $8.4 \mathrm{abEF}$ & $10.5 \mathrm{bcE}$ & $21.9 \mathrm{abcdeD}$ & $32.8 \mathrm{abcdC}$ & $42.9 \mathrm{abcB}$ & $53.3 \mathrm{aA}$ & $56.8 \mathrm{aA}$ \\
$\mathrm{S} 1301$ & $0.4 \mathrm{aG}$ & $1.6 \mathrm{aG}$ & $4.0 \mathrm{aFG}$ & $6.8 \mathrm{bEF}$ & $9.8 \mathrm{bcE}$ & $23.3 \mathrm{abD}$ & $33.9 \mathrm{abcC}$ & $44.4 \mathrm{abcB}$ & $56.8 \mathrm{aA}$ & $56.8 \mathrm{aA}$ \\
$\mathrm{S} 1600$ & $0.4 \mathrm{aG}$ & $1.8 \mathrm{aG}$ & $4.1 \mathrm{aFG}$ & $6.3 \mathrm{bEF}$ & $9.6 \mathrm{bcE}$ & $20.9 \mathrm{abcdeD}$ & $32.1 \mathrm{bcdeC}$ & $42.5 \mathrm{abcdB}$ & $54.3 \mathrm{aA}$ & $56.8 \mathrm{aA}$ \\
$\mathrm{S} 1809$ & $0.4 \mathrm{aI}$ & $1.5 \mathrm{aHI}$ & $4.5 \mathrm{aGH}$ & $8.0 \mathrm{abFG}$ & $8.7 \mathrm{cF}$ & $19.2 \mathrm{cdeE}$ & $30.1 \mathrm{cdefD}$ & $40.7 \mathrm{cdefC}$ & $48.1 \mathrm{bB}$ & $55.7 \mathrm{aA}$ \\
$\mathrm{S} 1823$ & $0.4 \mathrm{aI}$ & $1.6 \mathrm{aHI}$ & $5.1 \mathrm{aGH}$ & $8.3 \mathrm{abFG}$ & $10.6 \mathrm{bcF}$ & $17.9 \mathrm{eE}$ & $26.0 \mathrm{ghD}$ & $34.4 \mathrm{gC}$ & $42.0 \mathrm{cdB}$ & $50.2 \mathrm{bcA}$ \\
$\mathrm{S} 1875$ & $0.4 \mathrm{aH}$ & $1.6 \mathrm{aGH}$ & $4.6 \mathrm{aFG}$ & $8.0 \mathrm{abEF}$ & $11.8 \mathrm{bcE}$ & $22.4 \mathrm{abcD}$ & $33.6 \mathrm{abcC}$ & $44.2 \mathrm{abcB}$ & $54.6 \mathrm{aA}$ & $55.8 \mathrm{aA}$ \\
$\mathrm{S} 1967$ & $0.4 \mathrm{aH}$ & $1.7 \mathrm{aGH}$ & $4.6 \mathrm{aFG}$ & $7.9 \mathrm{bEF}$ & $11.5 \mathrm{bcE}$ & $22.2 \mathrm{abcdD}$ & $36.7 \mathrm{aC}$ & $45.1 \mathrm{abB}$ & $56.8 \mathrm{aA}$ & $56.8 \mathrm{aA}$ \\
S2535 & $0.4 \mathrm{aH}$ & $1.9 \mathrm{aH}$ & $5.9 \mathrm{aG}$ & $8.7 \mathrm{abFG}$ & $10.7 \mathrm{bcF}$ & $19.0 \mathrm{cdeE}$ & $28.9 \mathrm{defgD}$ & $36.9 \mathrm{fgC}$ & $44.1 \mathrm{bcdB}$ & $53.0 \mathrm{abA}$ \\
S2536 & $0.4 \mathrm{aI}$ & $1.6 \mathrm{aHI}$ & $5.0 \mathrm{aGH}$ & $8.3 \mathrm{abFG}$ & $11.2 \mathrm{bcF}$ & $18.3 \mathrm{deE}$ & $24.7 \mathrm{hD}$ & $34.7 \mathrm{gC}$ & $40.9 \mathrm{~dB}$ & $48.0 \mathrm{cA}$ \\
S2538 & $0.4 \mathrm{aH}$ & $1.9 \mathrm{aH}$ & $5.8 \mathrm{aG}$ & $9.9 \mathrm{abF}$ & $12.7 \mathrm{bF}$ & $20.0 \mathrm{bcdeE}$ & $30.5 \mathrm{cdefD}$ & $38.9 \mathrm{defC}$ & $45.3 \mathrm{bcB}$ & $53.6 \mathrm{abA}$ \\
Control & $0.4 \mathrm{aI}$ & $1.8 \mathrm{aI}$ & $5.7 \mathrm{aH}$ & $12.0 \mathrm{aG}$ & $17.9 \mathrm{aF}$ & $24.6 \mathrm{aE}$ & $32.4 \mathrm{bcdD}$ & $41.3 \mathrm{bcdeC}$ & $47.6 \mathrm{bB}$ & $56.8 \mathrm{aA}$ \\
\hline
\end{tabular}

Note. The means followed by the same letter do not differ statistically. Tukey's test was applied at the $1 \%$ probability level. Comparisons within the same column, lowercase letters; comparisons within the same line, capital letters. CV: $7.57 \%$.

In addition, the biological treatment provided better germination but more leaf damage than chemical treatments. This could be because these plants found it more difficult to lose the integuments (husk), which in most cases remained adhered to the cotyledons of the plants after their emergence. As these integuments were contaminated with pathogen structures on their surface, this longer period of contact between the pathogen and the host may have favored the appearance of lesions. Therefore, with biological treatment, the harmful action of the pathogen was delayed, allowing greater germination of the plants but later damage. Further research should explore the association of chemical and biological control to increase efficiency. This does not detract from the positive results presented here by biological control but suggests its use as another tool and not as the only form of control.

Comparing the results found here with those obtained previously with volatile and non-volatile metabolites, we can infer that the production of secondary compounds does not always indicate pathogen control, because the main objective of these tests is to verify the possible formation of these compounds by the candidate biocontrol agent. The in vitro production by the microorganism of these compounds does not necessarily mean that they will be produced in field conditions. On the other hand, a strain that could not produce such metabolites in vitro may produce them in natural field conditions.

The previous evaluations in competition assays helped select some efficient strains, because in the direct confrontation assay not only worked with isolated mechanisms as seen in the previous trials, but also with a set of mechanisms that when associated can promote efficient pathogen control allowing a greater chance of success when selecting strains for further testing. This can be evidenced in this germination assay, where from the pre-selected isolates, some were obtained that may produced metabolites with toxic effect on the studied pathogen, minimizing damage to plants. 
Table 6. Germination of cotton seeds (number of plants) treated with Bacillus to control Fusarium in a greenhouse.

\begin{tabular}{lll}
\hline Strain & Bacillus & 14 day of evaluation \\
\hline Negative Control & - & $21.00 \mathrm{a}$ \\
S685 & Bacillus thuringiensis & $15.20 \mathrm{~b}$ \\
S662 & Bacillus thuringiensis & $14.40 \mathrm{bc}$ \\
GF267 & & $13.20 \mathrm{bcd}$ \\
S1600 & Bacillus thuringiensis & $13.00 \mathrm{bcd}$ \\
S1809 & Bacillus thuringiensis & $12.40 \mathrm{bcde}$ \\
Carbendazim Tiram & - & $12.40 \mathrm{bcde}$ \\
S2536 & Paenibacillus alvei & $12.20 \mathrm{bcde}$ \\
S1301 & Bacillus thuringiensis & $11.60 \mathrm{cdef}$ \\
S1967 & Bacillus thuringiensis & $11.20 \mathrm{cdef}$ \\
GF266 & & $10.80 \mathrm{def}$ \\
S2538 & Bacillus megaterium & $10.60 \mathrm{def}$ \\
S1823 & Bacillus thuringiensis & $9.80 \mathrm{defg}$ \\
S2535 & Bacillus lentus & $9.40 \mathrm{efg}$ \\
S1875 & Bacillus thuringiensis & $8.20 \mathrm{fg}$ \\
Control with active Fusarium & - & $6.60 \mathrm{~g}$ \\
\hline
\end{tabular}

Note. The means followed by the same letter do not differ statistically. Tukey's test was applied at the $1 \%$ probability level. CV: $13.03 \%$.

Working with different strains of Bacillus to control a disease-causing fungal complex in cotton seedlings, Khiyami et al. (2014) found interaction between the organisms. A bacterium that has a good antagonistic effect to a certain fungus may not exercise it for another or even for a different isolate within the same species of fungus. This understanding can be extended to biocontrol agents where within the same species, some isolates may efficiently control a certain pathogen and others that do not have any antagonistic action. In this same work, the protective action of these bacteria was also noticed when used in seed treatment, providing greater protection to the plants in their initial stages of development, corroborating the results found in our work.

In direct confrontation assays, Shifa et al. (2015) selected from seven biocontrol agents with antifungal activity the bacteria with the best results in the in vitro assay to control Sclerotium rolfsii. The biocontrol agent they selected was the bacteria $B$. subtilis. In addition to the tests under laboratory conditions, this antagonist also obtained good results in greenhouse tests for the cultivation of peanuts (Arachis hypogaea L.). The greenhouse tests were conducted by either inoculating the seeds with the bacteria before planting (seed treatment) and applying it in the soil plus seed treatment. The best results were obtained when, in addition to the seed treatment, the bacterium was also inoculated into the soil which lead to a $93 \%$ reduction in the disease incidence. These results confirm the possibility of using these organisms as seed treatment, as proposed in our work.

In addition to the direct effect on the pathogen, these bacteria can also induce resistance in the host. Dutta et al. (2008) tested the effect of two isolates of PGPR (Bacillus cereus and Pseudomonas aeruginosa) to induce systemic resistance against Fusarium udum in pigeon pea and concluded that these bacteria could induce systemic resistance in the treated plants. In a review, Jiao et al. (2021) shows that PGPR can increasing crop yield and is a proven environment friendly way of controlling plant disease.

\section{Conclusion}

The adjustment made in the culture medium for the direct confrontation assays made it possible to conduct the tests without favoring one of the organisms to the detriment of the other, matching the conditions more competitive. The creation and use of the grading scale to evaluate the dual tests facilitated the standardization of the results making the selections more reliable. In vitro dual tests were used to select 13 strains that presented good competition results. Additionally, the scanning electron microscopy images of the confrontation zone between pathogen and biological control agent made illustrated morphological changes in the hyphae of the pathogen with the formation of irregular surfaces, expanded width, and hydrolysis. Of the 13 strains selected in the antagonism assay, four (S1301, S1967, S2535, and S2538) can produce non-volatile metabolites to reduce the growth of fungal mycelium until the last day of conducted assay. In the assays of volatile metabolites, two 
strains (S1823 and S2536) were able to interfere in fungal development until the tenth day of the experiment. Finally, in the greenhouse assays, 11 of the treatments and the negative control achieved statistically superior results to the positive control, which indicates a probable antagonistic potential of these bacteria to protect plants using seed treatment.

\section{References}

Abed, H., Rouag, N., Mouatassem, D., \& Rouabhi, A. (2016). Screening for Pseudomonas and Bacillus antagonistic rhizobacteria strains for the biocontrol of Fusarium wilt of chickpea. Eurasian Journal of Soil Science, 5, 182-191. https://doi.org/10.18393/ejss.2016.3.182-191

Agrawal, S. C., Khare, M. N., \& Agrawal, P. S. (1977). Biological control of Sclerotium rolfsii causing collar rot of lentil. Indian Phytopathology, 30, 176-179.

Alves, E. (2004). Curso introdutório à microscopia eletrônica de varredura. UFLA/FAEPE, Lavras.

Amorim, L., Rezende, J. A. M., \& Bergamin Filho, A. (2011). Manual de Fitopatologia. Piracicaba: Agronômica Ceres.

Arrebola, E., Sivakumar, D., \& Korsten, L. (2010). Effect of volatile compounds produced by Bacillus strains on postharvest decay in citrus. Biological Control, 53, 122-128. https://doi.org/10.1016/j.biocontrol.2009. 11.010

Asif, R., Muhammad, H. S., Zakki, S. A., Rasool, M. H., Waseem, M., Hayat, S., \& Muzammil, S. (2020). Saccharothrix algeriensis NRRL B-24137 potentiates chemical fungicide carbendazim in treating Fusarium oxysporum f.sp. vasinfectum-induced cotton wilt disease. Dose-Response, 1-9. https://doi.org/10.1177/ 1559325820960346

Assigbetse, K. B., Fernandez, D., Dubois, M. P., \& Geiger, J. P. (1994). Differentiation of Fusarium oxysporum f. sp. vasinfectum races on cotton by random amplified polymorphic DNA (RAPD) analyses. Phytopathology, 84, 622-626. https://doi.org/10.1094/Phyto-84-622

Baayen, R. P., O’Donnell, K., Bonants, P. J. M., Cigelnik, E., Kroon, L. P. N. M., Roebroeck, E. J. A., \& Waalwijk, C. (2000). Gene genealogies and AFLP analyses in the Fusarium oxysporum complex identify monophyletic and nonmonophyletic formae speciales causing wilt and rot disease. Phytopathology, 90, 891-900. https://doi.org/10.1094/PHYTO.2000.90.8.891

Beltrão, N. E. M. (1999). O agronegócio do Algodão no Brasil. Brasília: Embrapa CTT/EMBRAPA-CNPA.

Bennett, R. S., Spurgeon, D. W., DeTar, W. R., Gerik, J. S., Hutmacher, R. B., \& Hanson, B. D. (2011). Efficacy of four soil treatments against Fusarium oxysporum f. sp. vasinfectum race 4 on cotton. Plant Disease, 95, 967-976. https://doi.org/10.1094/PDIS-09-10-0696

Borém, A., \& Freire, E. C. (2014). Algodão do plantio à colheita. Ed. UFV, Viçosa.

Bossola, J. J., \& Russel, L. D. (1998). Electron Microscopy (2nd ed.). Jones and Bartlett Publishers, Boston.

Calvo, P., Zebelo, S., McNear, D., Kloepper, J., \& Fadamiro, H. (2019). Plant growth-promoting rhizobacteria induce changes in Arabidopsis thaliana gene expression of nitrate and ammonium uptake genes. Journal of Plant Interactions, 14, 224-231. https://doi.org/10.1080/17429145.2019.1602887

Chaurasia, B., Pandey, A., Palni, L. M., Trivedi, P., Kumar, B., \& Colvin, N. (2005). Diffusible and volatile compounds produced by an antagonistic Bacillus subtilis strain cause structural deformations in pathogenic fungi in vitro. Microbiology, 160, 75-81. https://doi.org/10.1016/j.micres.2004.09.013

Cia, E. (1977). Ocorrência e conhecimento das doenças de algodoeiro annual Gossypium hirsutum L. no Brasil. Summa Phytopatologica, 3, 167-193.

Cia, E., \& Salgado, C. L. (2005). Doenças do algodoeiro (Gossypium spp.). In H. Kimati, L. Amorim, A. Bergamim Filho, L. E. A. Camargo, \& J. A. M. Resende (Eds.), Manual de Fitopatologia: Doenças de plantas cultivadas. São Paulo: Ceres.

Cia, E., Fuzatto, M. G., Pizzinatto, M. A., Pettinelli Júnior, A., Paulo, E. M., Zimback, L., ... Vasconcelos, A. S. A. (1999). Comportamento de novas cultivares e linhagens na presença de doenças que ocorrem na cotonicultura da região meridional do Brasil. II Congresso Brasileiro de Algodão, Ribeirão Preto. Anais... EMBRAPA/CNPA.

CONAB (Companhia Nacional de Abastecimento). (2019). Retrieved from http://www.conab.gov.br 
Crane, J. M., Gibson, D. M., Vaughan, R. H., \& Bergstrom, G. C. (2013). Iturin levels on wheat spikes linked to biological control of Fusarium head blight by Bacillus amyloliquefaciens. Phytopathology, 103, 146-155. https://doi.org/10.1094/PHYTO-07-12-0154-R

Davis, R. M., Colyer, P. D., Rothrock, C. S., \& Kochman, J. K. (2006). Fusarium wilt of cotton: Population diversity and implications for management. Plant Disease, 90, 692-703. https://doi.org/10.1094/ PD-90-0692

Dennis, C., \& Webster J. (1971a). Antagonistic properties of species-groups of Trichoderma. I. Production of non-volatile antibiotic. Transactions British Mycological Society, 57, 25-39. https://oi.org/10.1016/ S0007-1536(71)80077-3

Dennis, C., \& Webster J. (1971b). Antagonistic properties of species-groups of Trichoderma. III. Hyphal interactions. Transactions British Mycological Society, 57, 363-369. https://doi.org/10.1016/S0007-1536 (71) $80050-5$

Dunlap, C. A., Schisler, D. A., Price, N. P., \& Vaughn, S. F. (2011). Cyclic lipopeptide profile of three Bacillus subtilis strains; antagonists of Fusarium head blight. Journal of Microbiology, 49, 603-609. https://doi.org/ 10.1007/s12275-011-1044-y

Dutta, S., Mishra, A. K., \& Dileep Kumar, B. S. (2008). Induction of systemic resistance against fusarial wilt in pigeon pea through interaction of plant growth promoting rhizobacteria and rhizobia. Soil Biology and Biochemistry, 40, 452-461. https://doi.org/10.1016/j.soilbio.2007.09.009

Farias, O., de Nascimento, L. C., Lima Cruz, J. M., Oliveira Silva, H. A., Oliveira, M., Alcântara Bruno, R. de L., \& Castro Arriel, N. H. (2019). Biocontrol potential of Trichoderma and Bacillus species on Fusarium oxysporum f. sp vasinfectum. Journal of Experimental Agriculture International, 34, 1-11. https://doi.org/ 10.9734/jeai/2019/v34i130166

Gong, A. D., Li, H. P., Yuan, Q. S., Song, X. S., Yao, W., He, W. J., ... Liao, Y. C. (2015). Antagonistic mechanism of iturin A and plipastatin A from Bacillus amyloliquefaciens S76-3 from wheat spikes against Fusarium graminearum. PLoS ONE, 10, 1-18. https://doi.org/10.1371/journal.pone.0116871

Gupta, R., \& Vakhlu, J. (2015). Native Bacillus amyloliquefaciens W2 as a potential biocontrol for Fusarium oxysporum R1 causing corm rot of Crocus sativus. European Journal of Plant Pathology, 143, $123-131$. https://doi.org/10.1007/s10658-015-0670-3

Jiao, X., Takishita, Y., Zhou, G., \& Smith, D. L. (2021). Plant associated Rhizobacteria for biocontrol and plant growth enhancement. Frontiers in Plant Science, 12, 634796. https://doi.org/10.3389/fpls.2021.634796

Katan, T., \& Katan, J. (1988). Vegetative-compatibility grouping of Fusarium oxysporum f.sp. vasinfectum from tissue and the rhizosphere of cotton plants. Phytopathology, 78, 852-855. https://doi.org/10.1094/ Phyto-78-852

Khiyami, M. A., Omar, M. R., Abd-Elsalam, K. A., \& Aly, A. A. E. (2014). Bacillus-based biological control of cotton seedling disease complex. Journal of Plant Protection Research, 54, 340-348. https://doi.org/ 10.2478/jppr-2014-0051

Kim, D. H., Martyn, R. D., \& Magill, C. W. (1993). Mitochondrial DNA (mtDNA)-relatedness among Formae speciales of Fusarium oxysporum in the Cucurbitaceae. Phytopathology, 83, 91-97. https://doi.org/ 10.1094/Phyto-83-91

Krug, H. P. (1936). Fusarium como causador da murcha do algodoeiro no Brasil (pp. 319-321). Reunião de Phytopatologistas do Brasil, 1, 1936, Rio de Janeiro. Annaes... Rio de Janeiro: Instituto de Biologia Vegetal.

Liu, K., McInroy, J. A., Hu, C. H., \& Kloepper, J. W. (2017). Selection and assessment of plant growth-promoting rhizobacteria for biological control of multiple plant diseases. Phytopathology, 107, 928-936. https://doi.org/10.1094/PHYTO-02-17-0051-R

Liu, K., McInroy, J. A., Hu, C. H., \& Kloepper, J. W. (2018). Mixtures of Plant-Growth-Promoting Rhizobacteria enhance Biological Control of multiple plant diseases and plant-growth promotion in the presence of pathogens. Plant Disease, 102, 67-72. https://doi.org/10.1094/PDIS-04-17-0478-RE

Lobo, Jr. M., \& Abreu, M. S. (2000). Inibição do crescimento micelial de Sclerotinia sclerotiorum por metabólitos voláteis produzidos por alguns antagonistas em diferentes temperaturas e pH's. Ciência e Agrotecnologia, 24, 521-526. 
Lori, G., Edel-Hermann, V., Gautheron, N., \& Alabouvette, C. (2004). Genetic diversity of pathogenic and nonpathogenic populations of Fusarium oxysporum isolated from carnation fields in Argentina. Phytopathology, 94, 661-668. https://doi.org/10.1094/PHYTO.2004.94.6.661

Machado, V., Berlitz, D. L., Matsumura, A. T. S., Santin, R. C. M., Guimarães, A., Silva, M. E., \& Fiuza, L. M. (2012). Bactérias como agentes de controle biológico de fitonematoides. Oecologia Australis, 16, $165-182$. https://doi.org/10.4257/oeco.2012.1602.02

Monnerat, R. G., Batista, A. C., Medeiros, P. T., Martins, E., Melatti, V. M., Praça, L. B., ... Berry, C. (2007). Screening of Brazilian Bacillus thuringiensis isolates active against Spodoptera frugiperda, Plutella xylostella and Anticarsia gemmatalis. Biological Control, 41, 291-295. https://doi.org/10.1016/j.biocontrol. 2006.11.008

Ntushelo, K., Ledwaba, L. K., Rauwane, M. E., Adebo, O. A., \& Njobeh, P. B. (2019). The Mode of Action of Bacillus Species against Fusarium graminearum, Tools for Investigation, and Future Prospects. Toxins, 11(10), 606. https://doi.org/10.3390/toxins11100606

Patel, H., Tscheka, C., Edwards, K., Karlsson, G., \& Heerklotz, H. (2011). All-or-none membrane permeabilization by fengycin-type lipopeptides from Bacillus subtilis QST713. Biochimica et Biophysica Acta, 1808, 2000-2008. https://doi.org/10.1016/j.bbamem.2011.04.008

Punja, Z. K., \& Utkhede, R. S. (2003). Using fungi and yeasts to manage vegetable crop diseases. Trends in Biotechnology, 21, 400-407. https://doi.org/10.1016/S0167-7799(03)00193-8

Romero, D., Vicente, A., Rakotoaly, R. H., Dufour, S. E., Veening, J. W., Arrebola, E., ... García, A. P. (2007). The iturin and fengycin families of lipopeptides are key factors in antagonism of Bacillus subtilis toward Podosphaera fusca. Molecular Plant-Microbe Interactions, 20, 430-440. https://doi.org/10.1094/MPMI20-4-0430

Serra, I. M. R. S., \& Silva, G. S. (2005). Caracterização biológica e fisiológica de isolados de Sclerotium rolfsii obtidos de pimentão no Estado do Maranhão. Fitopatologia Brasileira, 30, 61-66. https://oi.org/10.1590/ S0100-41582005000100010

Shifa, H., Gopalakrishnan, C., \& Velazhahan, R. (2015). Efficacy of Bacillus subtilis G-1 in suppression of stem rot caused by Sclerotium rolfsii and growth promotion of groundnut. Plant Pathology, 8, 111-118. https://doi.org/10.5958/2230-732X.2015.00015.7

Soares, P. L. M., \& Santos, J. M. (2006). Utilização de fungos nematofágos no controle biológico de fitonematoides. In S. A. Bortoli, J. R. Boiça, \& J. E. M. Oliveira (Eds.), Agentes de controle biológico: metodologia de criação, multiplicação e uso. Jaboticabal: FUNEP.

Sturz, A. V., \& Nowak, J. (2000). Endophytic communities of rhizobacteria and the strategies required to create yield enhancing associations with crops. Applied Soil Ecology, 15, 183-190. https://doi.org/ 10.1016/S0929-1393(00)00094-9

Tian, B., Yang, J., \& Zhang, K. Q. (2007). Bacteria used in the biological control of plantparasitic nematodes: populations, mechanisms of action, and future prospects. FEMS Microbiology Ecology, 61, 197-213. https://doi.org/10.1111/j.1574-6941.2007.00349.x

Veigas, A. P. (1935). A murcha do algodoeiro. Revista de Agricultura, 10, 49-51.

Zhang, X. Y., Li, B. Q., Wang, Y., Guo, Q. G., Lu, X. Y., Li, S., \& Ma, P. (2013). Lipopeptides, a novel protein, and volatile compounds contribute to the antifungal activity of the biocontrol agent Bacillus atrophaeus CAB-1. Applied Microbiology and Biotechnology, 97, 9525-9534. https://doi.org/10.1007/s00253013-5198-X

\section{Copyrights}

Copyright for this article is retained by the author(s), with first publication rights granted to the journal.

This is an open-access article distributed under the terms and conditions of the Creative Commons Attribution license (http://creativecommons.org/licenses/by/4.0/). 